\title{
ANALISIS KONFLIK BATIN TOKOH UTAMA DAN NILAI PENDIDIKAN KARAKTER NOVELET KETIKA MAS GAGAH PERGI KARYA HELVY TIANA ROSA SERTA RELEVANSINYA SEBAGAI BAHAN AJAR SASTRA DI SMA
}

\author{
Rahmadhani Briliannisa Widowati, Nugraheni Eko Wardani, Slamet Mulyono \\ Universitas Sebelas Maret \\ Surel: rahmadhanisaa@ student.uns.ac.id
}

\begin{abstract}
Abstrak: Bentuk penelitian ini berupa penelitian deskripstif kualitatif. Sumber data penelitian ini adalah novel dan informan. Teknik pengambilan subjek penelitian adalah purposive sampling. Teknik pengumpulan data yang digunakan adalah teknik baca, catat dan wawancara. Uji validitas data menggunakan triangulasi sumber data dan teori. Teknik analisis data yang digunakan adalah teknik analisis mengalir. Hasil penelitian ini menunjukkan bahwa: (1) tema yang diangkat dalam novelet adalah ketuhanan, tokohnya protagonis, alurnya merupakan alur maju, cerita berlatar di Jakarta pada tahun 1994, sudut pandang orang pertama pelaku utama, amanatnya adalah jadilah agen kebaikan yang baik; (2) tokoh Gagah dan Yudi memiliki unsur id, ego, dan superego, tokoh Gita memiliki id dan ego yang tinggi serta mengalami konflik batin paling kuat; (3) nilai pendidikan karakter yang terkandung dalam novelet meliputi Religius, jujur, toleransi, disiplin, kreatif, mandiri, demokratis, rasa ingin tahu, bersahabat/ komunikatif, cinta damai, gemar membaca, peduli lingkungan, peduli sosial, tanggung jawab; dan (4) novelet Ketika Mas Gagah Pergi relevan untuk dijadikan bahan ajar jika dilihat dari keterkaitannya dengan tujuan instruksional yang harus dicapai, juga dari aspek isi, penyajian, bahasa, dan kegrafikaan.
\end{abstract}

Kata kunci: penokohan, konflik batin, novelet Ketika Mas Gagah Pergi, nilai pendidikan karakter, relevansi dengan bahan ajar

\section{INNER CONFLICT ANALYSIS OF THE MAIN CHARACTER AND CHARACTER EDUCATION VALUE IN KETIKA MAS GAGAH PERGI NOVELET BY HELVY TIANA ROSA AND ITS RELEVANCE AS LEARNING MATERIAL OF LITERATURE IN SENIOR HIGH SCHOOL}

\begin{abstract}
This form of research is descriptive qualitative research. The data sources of this research are novel and informants. Technique of taking research subject is purposive sampling. Data collection techniques used is technique read dan write dan interviews. Test the validity of data using triangulation of data sources and theory. Data analysis technique used is flow analysis technique. The result show that: (1) the theme raised in the novelet is the deity, the protagonist, the plot is a forward flow, the story set in Jakarta in 1994, the point of view of the first person the main character, his message is to be a good agent of Goodness; (2) Gagah and Yudi characters have elements id, ego, and superego, Gita character has high id and ego and experiencing the most powerful inner conflicts; (3) the value of character education contained in the novelet includes religious, honest, tolerant, disciplined, creative, independent, democratic, curiosity, friendly/communicative, peace loving, reading, caring, caring, responsible; and (4) the novelet Ketika Mas Gagah Pergi is relevant to be used as a teaching material when viewed from its relation with instructional objectives to be achieved, also from the aspect of content, presentation, language, and graph.
\end{abstract}

Keyword: characterization, internal conflict, novelet Ketika Mas Gagah Pergi, character education value, relevance to teaching material 


\section{PENDAHULUAN}

Karya sastra merupakan hasil cipta, rasa, dan karya seorang pengarang (Endraswara, 1993: 96). Sejalan dengan hal tersebut, Atar Semi juga berpendapat bahwa karya sastra adalah suatu bentuk dan hasil pekerjaan seni kreatif yang objeknya adalah manusia dan kehidupannya dengan menggunakan bahasa sebagai mediumnya (Sehandi, 2014 : 53).

Sastra dibagi menjadi tiga, yaitu prosa fiksi, puisi, dan drama. Ada tiga bentuk prosa yang dikenal, yaitu novel, novelet, dan cerpen. Nurgiyantoro mengatakan bahwa novel merupakan sebuah karya sastra fiksi yang menawarkan sebuah dunia yang berisi model kehidupan yang diidealkan, dunia imajinasi, yang dibangun melalui berbagai unsur intrinsiknya (2005: 4) utamanya konflik batin yang terdapat dalam diri tokoh utama. Novel dan novelet pada dasarnya tidak memiliki perbedaan yang signifikan. Oleh karena itu, maka antara novel dan novelet memiliki pengertian yang sama, termasuk unsur pembangunnya.

Pada sebuah cerita terdapat tokoh yang memiliki kepribadian atau watak yang diceritakan di dalamnya dan merupakan objek kajian yang sering dibahas. Membahas kepribadian atau watak seorang tokoh dapat melalui kajian psikologi sastra. Sastra dan psikologi memiliki hubungan yang erat. Sebagaimana sosiologi refleksi, psikologi sastra pun mengenal karya sastra sebagai pantulan kejiwaan. Pengarang akan menangkan gejala jiwa kemudian diolah ke dalam teks dan dilengkapi dengan kejiwaannya (Suaka, 2013: 228). Tujuan psikologi sastra adalah memahami aspekaspek kejiwaan yang terkandung di dalam suatuu karya (Minderop, 2013: 54).

Berdasarkan Permendikbud Nomor 24 Tahun 2016 tentang KI dan KD Pelajaran Kurikulum 2013, salah satu kompetensi dasar yang harus dicapai oleh siswa SMA kelas XII yaitu Kompetensi Dasar 3.9 yang berbunyi "Menganalisis isi dan kebahasaan novel". Kurikulum 2013 menuntut adanya tiga aspek kompetensi yaitu kognitif, afektif, dan psikomotorik. Wibowo (2013: 136) mengatakan bahwa pembelajaran sastra diarahkan pada tumbuhnya sikap apresiatif terhadap karya sastra, yaitu sikap menghargai karya sastra. Dalam pembelajaran sastra ditanamkan tentang pengetahuan karya sastra (kognitif), ditumbuhkan kecintaan terhadap karya sastra (afektif), dan dilatih keterampilan menghasilkan karya sastra (psikomotorik).

Novelet Ketika Mas Gagah Pergi karya Helvy Tiana Rosa ini membahas tentang cerita kehidupan seseorang dari yang jauh dari agama, mementingkan kehidupan dunianya, dan bangga mendapat kesuksesan di dunia menjadi seorang yang baik dan dapat menginspirasi orang disekitarnya mulai dari mengenal agama, mengajak orang untuk berbuat baik, mencontohkan hal-hal baik kepada lingkungannya, dan membuat orang di sekitarnya menjadi termotivasi untuk menjadi lebih baik, serta dekat dengan Tuhan. Selain itu, sosok Mas Gagah yang menjadi tokoh utama merupakan sosok yang dapat dicontoh kepribadiannya.

Berdasarkan uraian di atas, peneliti bermaksud untuk mengkaji karakter tokoh utama dalam novelet Ketika Mas Gagah Pergi karya Helvy Tiana Rosa dengan pendekatan psikologi sastra dan mencari nilai pendidikan karakter novel/ novelet serta relevansinya sebagai materi pembelajaran sastra di SMA.

\section{METODE PENELITIAN}

Penelitian ini dilaksanakan selama lima bulan, yaitu dari bulan Januari 2018 sampai dengan Mei 2018. Penelitian ini termasuk penelitian kualitatif deskriptif dengan menggunakan metode analisis isi dan menggunakan pendekatan psikologi sastra. Data dan sumber data yang digunakan adalah ungkapan-ungkapan dalam novelet Ketika Mas Gagah Pergi karya Helvy Tiana Rosa yang menunjukkan kepribadian tokoh dan hasil 
wawancara dengan beberapa siswa dan guru SMA Negeri 1 Klaten dan SMA N 1 Klaten serta sastrawan. Pengambilan subjek penelitian dilakukan dengan teknik purposive sampling. Pengumpulan data dilakukan dengan analisis dokumen dan wawancara. Uji validitas data yang digunakan dalam penelitian ini adalah teknik triangulasi teori dan triangulasi sumber. Teknik analisis data yang digunakan adalah teknik analisis model interaktif.

\section{HASIL PENELITIAN DAN \\ PEMBAHASAN}

\section{Struktur Novelet Ketika Mas Gagah Pergi Karya Helvy Tiana Rosa}

Novel sebagai karya sastra fiksi memiliki unsur-unsur pembangun yang meliputi tema, tokoh dan penokohan, alur atau plot, latar, sudut pandang, dan amanat. Berikut struktur yang dianalisis dalam novelet Ketika Mas Gagah Pergi karya Helvy Tiana Rosa.

\section{Tema}

Waluyo (2011: 7) mengatakan bahwa tema adalah gagasan pokok dalam cerita fiksi. Tema cerita bisa dapat diketahui oleh pembaca dari judul novel, atau petunjuk setelah judul. Namun, perlu juga dibaca beberapa kali untuk mengetahui tema dari suatu novel. Novelet Ketika Mas Gagah Pergi karya Helvy Tiana Rosa ini secara umum memiliki tema yaitu ketuhanan dan secara rinci bertemakan perubahan seseorang menjadi lebih baik. sebagaimana yang ada dalam kutipan.

"Mas Ketemu Kiai hebat di Madura," cerita Mas Gagah antusias. "Namanya Kiai Ghufron! Subhanallah, orangnya sangat bersahaja, santri-santrinya luar biasa! Di sana Mas memakai waktu luang Mas untuk mengaji pada beliau. Dan tiba-tiba, dunia jadi lebih benderang!" tambahnya penuh semangat (Rosa, 2014: 4).

Bukti tersebut menjelaskan bagaimana sososk Mas Gagah menemukan
"Tuhan" dalam perjalanannya kemudian mencintai agamanya (agama Islam) dengan seutuhnya. Mas Gagah mulai merasakan betapa kedekatan emosi dengan Tuhan dan Islam merupakan sebuah karunia yang diberikan kepada-Nya.

\section{Tokoh dan Penokohan}

Berdasarkan perannya, tokoh dalam novel terdiri dari tokoh utama dan tokoh tambahan. Namun, dalam penelitian ini peneliti fokus meneliti penokohan pada tokoh utama. Tokoh utama dalam novelet Ketika Mas Gagah Pergi adalah Mas Gagah, Gita, dan Yudi, Secara khusus novelet ini menggambarkan sosok tokoh yang menjadi lebih baik di balik tantangan dan pertentangan yang ada. Seperti halnya Mas Gagah yang berubah menjadi lebih baik dengan penggambaran dalam novel sebagai berikut :

Di satu sisi kuakui Mas Gagah tambah alim. Shalat tepat waktu, berjamaah di masjid, ngomongnya soal agama terus. Kalau aku lagi ngintip di lubang kunci, ia pasti lagi ngaji atau baca buku Islam. Dan kalau aku mampir di kamarnya, ia dengan senang hati menguraikan isi buku yang dibacanya, atau malah menceramahiku (Rosa, 2014: 6)

\section{Latar atau Setting}

Latar atau setting meliputi tempat, waktu, dan budaya yang digunakan dalam suatu cerita. Latar dalam suatu cerita bisa bersifat faktual atau bisa pula yang imajiner. Latar berfungsi untuk memperkuat atau mempertegas keyakinan pembaca terhadap jalannya suatu cerita. Latar dibagi menjadi tiga jika dilihat dari arti yang lengkap, yaitu meliputi aspek ruang dan waktu terjadinya peristiwa, serta aspek suasana yang timbul dalam sebuah peristiwa. Berikut cuplikan yang menunjukkan latar tempat terjadinya suatu peristiwa. Dapat diketahui dari kutipan berikut.

Hujan turun rintik-rintik, lalu makin deras. Mobil kami susah payah 
masuk di jalan kecil yang hanya pas untuk satu mobil. Jalan kumuh dengan rumah-rumah triplek dan kardus berjejalan, di sebuah kolong jembatan di daerah Jakarta Utara (Rosa, 2014: 19).

Kolong jembatan daerah Jakarta Utara. Di sinilah Mas Gagah sering berbagi dengan banyak orang yang membutuhkan. Mas Gagah menjadikan tempat ini untuk berdakwah, belajar, juga membantu sesama.

Latar waktu bisa berupa penyebutan waktu secara angka maupun hanya menyebutkan sekilas, seperti tadi, kemarin, nanti, sejak dulu, pagi, siang, sore, malam, dan lain sebagainya. Dalam novelet Ketika Mas Gagah Pergi, memiliki latar waktu sebagai berikut.

Mas Gagah berubah! Ya, sudah beberapa bulan belakangan ini Mas, sekaligus saudara kandungku satusatunya itu benar-benar berubah (Rosa, 2014: 1)

Latar sosial yang digunakan dalam novelet menggambarkan kondisi saat kejadian tersebut di mana sosok Gita belum menerima Mas Gagah berubah. Seperti pada cuplikan berikut.

Aku sedih. Aku kehilangan. Mas Gagah yang dulu, yang selalu kubanggakan kini entah ke mana.... (Rosa, 2014: 4).

\section{Plot atau alur}

Berdasarkan pembagian alur (plot) menurut Kosasih, novelet Ketika Mas Gagah Pergi menggunakan alur (plot) normal. (1) Pengenalan situasi cerita (babak awal), (2) Pengungkapan peristiwa, (3) Menuju pada adanya konflik, (4) Puncak konflik, dan (5) Penyelesaian. Alur (plot) normal adalah alur di mana cerita tersebut berjalan secara runtut atau bisa dikatakan novelet ini memiliki alur maju.

\section{Sudut Pandang}

Sudut pandang merupakan cara yang digunakan oleh pengarang sebagai sarana menyajikan tokoh, tindakan, latar, dan berbagai peristiwa yang membentuk cerita dalam sebuah karya fiksi (Kasnadi dan Sutejo, 2010: 22). Novelet Ketika Mas Gagah Pergi memiliki sudut pandang penulis berperan langsung sebagai orang pertama, sebagai tokoh yang terlihat dalam cerita yang bersangkutan. Hal ini dapat ditandai dengan pengarang menggunakan kata "aku" atau "saya" dalam cerita yang disebut sebagai sudut pandang orang pertama. Dalam sudut pandang orang pertama ini pengarang menjadi tokoh utama yang disebut sudut pandang orang pertama pelaku utama. Sebagaimana kutipan berikut.

Hari-hari berlalu. Aku dan Mas Gagah mulai dekat lagi, meski aktivitas yang kami lakukan berbeda dengan yang dahulu... (Rosa, 2014: 13).

Pagi itu aku kembali berlari-lari mengejar bus jurusan Pulo GadungDepok dengan seragam putih abuabu (Rosa, 2014: 31).

\section{Gaya Bahasa}

Gaya bahasa adalah cara pengarang menyampaikan cerita. Setiap pengarang memiliki cara sendiri untuk menggambarkan cerita agar lebih hidup dan menarik. Novelet Ketika Mas Gagah Pergi menggunakan gaya bahasa yang menarik pembaca karena menceritakan kedekatan seorang Gita dengan Gagah dengan bahasa adik-kakak yang menarik pembaca. Membuat pembaca merasakan sebuah hubungan adik-kakak yang terjalin erat dan manis. Seperti dalam kutipan berikut.

Sejak kecil aku sangat dekat dengannya. Tak ada rahasia di antara kami. Ia selalu mengajakku ke mana ia pergi. Ia yang menolong saat aku butuh pertolongan. Ia menghibur dan membujuk di saat aku bersedih. Membawakan oleholeh sepulang sekolah dan mengajariku mengaji. Pendek kata, ia selalu melakukan hal-hal baik, 
menyenangkan, dan berarti banyak untukku (Rosa, 2014: 2).

\section{Amanat}

Amanat biasanya memberikan manfaat dalam kehidupan secara praktis. Amanat dibuat oleh pengarang dapat disebut juga pesan terselubung yang disampaikan oleh pengarang (Rokhmansyah, 2014: 33). Sebagaimana tema yang telah dijelaskan bahwa novelet ini berisi tentang Ketuhanan dan seseorang yang berusaha menjadi lebih baik dari sebelumnya. Maka amanat yang adapat diambil adalah sampaikanlah kebaikan kapan pun dan di mana pun. Walaupun sedikit, orang yang berilmu hendaknya berbagi kepada orang lain. Karena ketika ilmu itu dibagikan, maka ilmu itu tidak habis, melainkan menjadi bertambah dan mendapat kebaikan pahala dati Tuhan. Seperti kutipan berikut.

Begitulah. Di mana ia berada di sana selalu banyak yang memperhatiaknnya. Wajar. Habis yang diangkat menjadi bahan pembicaraan selalu yang menarik, seru, aktual, dan hebat. Belum lagi manuvernya (Rosa, 2014: 39).

\section{Deskripsi Konflik Batin Tokoh Utama yang Dikaitkan pada Tiap Unsur Intrinsik dalam Novelet Ketika Mas Gagah Pergi Karya Helvy Tiana Rosa}

Teori yang akan digunakan adalah teori psikoanalisis Sigmund Freud. Freud mengemukakan bahwa struktur kepribadian manusia mengandung tiga komponen yang disebut id (tidak sadar), ego (tidak sadar, prasadar, sadar), dan superego (tidak sadar, prasadar, sadar). Id mengungkapkan tujuan hakiki dari keinginan dan kebutuhan organisme individu. Ego selalu mencari cara memenuhi kebutuhan dan kepuasan. Superego yang mengendalikan keinginankeinginan tersebut.

Selain itu, subdisiplin ilmu yang akan membahas tentang kepribadian tokoh dalam cerita adalah konflik batin yang muncul. Konflik merupakan sesuatu yang dramatik, mengacu pada pertentangan antara dua kekuatan yang seimbang dan menyiratkan aksi-aksi balasan. Dalam sebuah cerita, konflik adalah pertentangan dua atau lebih karakter yang ada di dalam cerita.

Tokoh utama dalam novelet ini adalah Mas Gagah, Gita, dan Yudi. Jika ditinjau dengan analisis teori Sigmund Freud, ketiga tokoh utama ini memiliki $i d$, ego, dan superego yang berbeda. Konflik batin yang dialami tokoh Gagah tidak terlalu terlihat. Hanya saja, ketika muncul dalam cerita, sosok ini sudah melewati masa konflik yang ada di dalam batinnya setelah bertemu seseorang yang dapat mengubah hidupnya. Sosok Gagah dapat mengatur id, ego, dan superegonya dengan baik. Ego nya selalu dapat mengalahkan id nya melalui superego.

"Mas ketemu kiai hebat di Madura," cerita Mas Gagah antusias. "Namanya Kiai Ghufron! Subhanallah, orangnya sangat bersahaja, santri-santrinya luar biasa! Di sana Mas memakai waktu luang Mas untuk mengaji pada beliau. Dan tiba-tiba dunia jadi lebih benderang!" tambahnya penuh semangat. "Nanti kapan-kapan kita ke sana ya, Git (Rosa, 2014: ).

Gita adalah sosok yang mengalami konflik batin paling terlihat dalam cerita ini. Mulai dari sosoknya yang tidak terima atas perubahan Mas Gagah, lambat laun ia mulai memahami dan juga ikut berubah seperti Mas Gagah. Pada awalnya Gita adalah sosok yang tidak dapat mengatur $i d$, ego, dan superego nya dengan baik. ia termasuk orang yang mudah tidak terima dan gemar protes dengan keadaan yang tidak sesuai dengan apa yang ia inginkan. Berbeda dengan sosok Yudi, Yudi ketika masuk dalam cerita ini menjadi seseorang yang lebih bisa mengatur id, ego, dan superegonya lebih dari Mas Gagah. Yudi adalah sosok yang tidak begitu terlihat konflik batinnya. Hanya konflik-konflik 
kecil ketika ia harus menghadapi orangorang yang ada di sekitarnya.

\section{Nilai Pendidikan Karakter dalam Novelet Ketika Mas Gagah Pergi Karya Helvy Tiana Rosa}

Novel sebagai karya sastra yang baik hendaknya bersifat dulce et utile seperti yang dikatakan Ismawati (2013:

115) bahwa sastra diakui sebagai salah satu alat untuk menyampaikan pengajaran (pendidikan) yang berguna dan menyenangkan (dulce et utile). Selain memberikan kesenangan, novel juga harus memiliki nilai kebermanfaatan, salah satunya memberikan nilai pendidikan karakter bagi pembaca.

Novelet Ketika Mas Gagah Pergi karya Helvy Tiana Rosa dapat dikatakan sebagai karya sastra yang sesuai dengan dulce et utile jika dilihat dari nilai pendidikan karakter yang terkandung di dalamnya. Novelet Ketika mas Gagah Pergi karya Helvy Tiana Rosa setelah dianalisis memiliki 15 nilai pendidikan karakter yaitu (1) religius, (2) jujur, (3) toleransi, (4) disiplin, (5) kerja keras, (6) kreatif, (7) mandiri, (8) demokratis, (9) rasa ingin tahu, (10) bersahabat/ komunikatif, (11) cinta damai, (12) gemar membaca, (13) peduli lingkungan, (14) peduli sosial, dan (15) tanggung jawab. Nilai yang paling dominan adalah nilai religius, cinta damai, penduli sosial, dan peduli lingkungan.

\section{Religius}

"Mas Gagah! Mas Gagaaahhh!" teriakku kesal sambil mengetuk pintu kamar Mas Gagah keras-keras. Tak ada jawaban. Padahal kata Mama Mas Gagah ada di kamarnya. Kulihat stiker metalik di depan pintu kamar Mas Gagah. Tulisan berbahasa arab gundul. Tak bisa kubaca. Tapi aku bisa membaca artinya : Jangan masuk sebelum memberi salam! (Rosa, 2014: 4).

\section{Cinta damai}

"Sebenarnya massa sudah tenang, mendengar apa yang disampaikan oleh Gagah. Bahwa Islam itu mengajarkan kedamaian dan membawa pada keselamatan. Gagah bahkan bilang saatnya kita bergandeng tangan dan berjabat hati untuk membangun negeri mereka secara bergerombolan pun beranjak pergi," tambah salah satu teman Mas Gagah (Rosa, 2014: 25).

\section{Peduli sosial}

Mobil kami terus berjalan, jauh sekali, melintasi daerah yang asing bagiku. Mas Gagah berhenti sekali di sebuah supermarket kecil. Aku mengerutkan kening melihatnya membeli makanan kering, mie instan beberapa kardus, buku, dan alat-alat tulis. Mau ke mana?

Hujan turun rintik-rintik, lalu makin deras. Mobil kami susah payah masuk di jalan kecil yang hanya pas untuk satu mobil. Jalan kumuh dengan rumah-rumah triplek dan kardus berjejeran, di sebuah kolong jembatan di Jakarta Utara (Rosa, 2014: 19).

\section{Peduli lingkungan}

"Nyok kite sholat dulu, Gah. Noh mushole kite nyang bulan lalu belum kelar, sekarang ude bagus gara-gara elo dan temen-temen lo," Ujar Bang Urip. "Seperti yang lo bilang, biar dikit ada tanamannya mah!" (Rosa, 2014: 21).

Nilai pendidikan karakter ini dapat dijadikan sebagai pedoman siswa untuk mengembangkan perilaku positif. Nilai pendidikan karakter yang terdapat dalam novelet dapat dilihat dari perwatakan dan perilaku tokoh. 
Relevansi Novelet Ketika Mas Gagah Pergi Karya Helvy Tiana Rosa sebagai Bahan Ajar Sastra di SMA

Bahan ajar adalah hal terpenting yang dibutuhkan dalam proses belajar mengajar. Bahan ajar yang baik adalah bahan ajar yang sesuai dengan kebutuhan siswa. Kebutuhan siswa berarti sesuai dengan keadaan zaman dan kurikulum yang sedang berjalan. Namun selain buku teks, ada sumber bahan ajar yang lain yaitu buku non teks (pengayaan). Fungsi dari buku nonteks ini salah satunya ungtuk memperluas materi yang dipelajari. Buku nonteks (pengayaan) terdiri dari kepribadian, science, dan keterampilan.

Bahan ajar atau materi pembelajaran (instructional materials) secara garis besar terdiri dari pengetahuan, keterampilan, dan sikap yang harus dipelajari siswa dalam rangka mencapai standar kompetensi yang telah ditentukan. Secara terperinci, jenisjenis materi pembelajaran terdiri dari pengetahuan (fakta, konsep, prinsip, prosedur), keterampilan, dan sikap atau nilai (Depdiknas, 2006: 4).

Berdasarkan hal di atas, materi pelajaran harus sesuai dengan tujuan instruksional, maka dapat dikaitkan dengan kompetensi yang harus dicapai oleh siswa. Kesesuaian tersebut dapat dilihat dalam Permendikbud Nomor 24 Tahun 2016 tentang KI dan KD Pelajaran Kurikulum 2013 untuk siswa SMA kelas XII. KD 3.9 berbunyi "Menganalisis isi dan kebahasaan novel".

Novelet sebagai bahan ajar sastra di SMA berarti menjadikan novelet sebagai sarana penyampaian materi apresiasi sastra di SMA. Siswa akan diminta untuk membaca sebuah novelet, kemudian siswa akan mengapresiasi sastra berdasarkan novelet tersebut. Di dalamnya siswa akan mempelajari unsur-unsur yang terkandung di dalam novelet tersebut juga dapat memberi tanggapan menurut pemahaman siswa terhadap novelet tersebut. Tidak hanya itu, dari cerita yang ada di dalam novelet siswa juga dapat mengambil banyak nilai pendidikan karakter yang dapat membangun karakter di dalam diri siswa.

Salah satu tugas pendidik adalah menyediakan suasana belajar yang menyenangkan. Pendidik harus mencari cara untuk membuat pembelajaran menjadi menyenang-kan dan mengesampingkan ancam-an selama proses pembelajaran. Salah satu cara untuk membuat pembelajaran menjadi menyenang-kan adalah dengan menggunakan bahan ajar yang menyenangkan pula, yaitu bahan ajar yang dapat membuat peserta didik merasa tertarik dan senang mempelajari bahan ajar tersebut.

Salah satu bahan ajar yang menarik adalah novelet Ketika Mas Gagah Pergi karya Helvy Tiana Rosa. Novelet ini memungkinkan untuk dijadikan sebagai bahan ajar sastra di SMA karena memiliki kesesuaian dengan kompetensi dasar yang harus dicapai siswa. Selain itu, novelet ini juga tidak mengandung nilai-nilai negatif yang dapat memberikan pengaruh buruk kepada siswa. Nilai-nilai yang terkandung di dalamnya merupakan nilai-nilai positif dan memuat pendidikan karakter yang dapat memotivasi siswa. Sebagai karya sastra, novelet ini juga memenuhi prinsip dulce et utile, di mana sebuah karya sastra selain menarik juga harus memberikan manfaat.

Hal ini sejalan dengan apa yang disampaikan oleh Anik Hidayati Guru Bahasa Indonesia yang menyatakan bahwa dalam novelet Ketika Mas Gagah Pergi karya Helvy Tiana Rosa memiliki banyak nilai-nilai yang bermanfaat ketika siswa membacanya juga mengenal jenis baru dalam karya sastra yang belum begitu familiar di telinga mereka, yaitu novelet.

Kelayakan sebuah novel atau novelet untuk dijadikan sebagai materi pembelajaran sastra di SMA khususnya sebagai buku nonteks pelajaran dapat dilihat dari empat segi, yaitu (1) kelayakan isi/materi, (2) kelayakan penyajian, (3) kelayakan bahasa, dan (4) kelayakan kegrafikan sesuai yang tertuang dalam Permendikbud Nomor 8 Tahun 2016. Jika 
ditinjau dari aspek tersebut, maka novelet ini termasuk novelet yang sudah sesuai dengan standar isi yang seharusnya ada dalam buku nonteks pelajaran.

\section{SIMPULAN}

Berdasarkan pada penelitian yang telah dilakukan mengenai struktur, kajian psikologi sastra berupa konflik batin, nilai pendidikan karakter, dan relevansi novelet Ketika Mas Gagah Pergikarya Helvy Tiana Rosa sebagai bahan ajar sastra di SMA dapat ditarik beberapa kesimpulan.

Novelet Ketika Mas Gagah Pergi karya Helvy Tiana Rosa memiliki struktur yang saling berkaitan dan saling melengkapi satu sama lain. Struktur tersebut terdiri dari tema, latar (setting), alur (plot), penokohan, sudut pandang, gaya bahasa, dan amanat. Dari unsur-unsur tersebut memiliki keterkaitan dilihat dari tema secara keseluruhan yaitu tentang Ketuhanan dan perubahan menjadi orang yang lebih baik. dari terma tersebut, semua unsur mempengaruhi jalannya cerita dan membuat cerita menjadi menarik. Setiap unsur memiliki keterkaitan dan tidak bisa berdiri sendiri. Hal ini yang membuat novelet Ketika Mas Gagah Pergi karya Helvy Tiana Rosa merupakan salah satu novelet yang baik selain dilihat dari isinya. Tokoh utama dalam novelet Ketika Mas Gagah Pergi karya Helvy Tiana Rosa yaitu Gita Ayu Pratiwi, Gagah Perwira Pratama, dan Yudhistira Arifin yang digolongkan menurut intensitas keluarnya tokoh dalam cerita, ketiganya digolongkan menjadi tokoh utama-protagonis. Tokoh utama akan dianalisis konflik batin yang ada pada dirinya. Konflik batin adalah kondisi kejiwaan seseorang yang mengalami pertentangan antardua atau lebih karakter yang ada di dalam cerita. Dalam mengetahui konflik batin tokoh utama, maka peneliti menggunakan teori psikoanalisis Sigmund Freud. Freud mengemukakan bahwa struktur kepribadian manusia mengandung tiga komponen yang disebut id (tidak sadar), ego (tidak sadar, prasadar, sadar), dan superego (tidak sadar, prasadar, sadar).

Konflik batin terjadi pada diri masing-masing tokkoh dengan alasan dan penyebab yang berbeda-beda. Konflik batin yang dialami Gita adalah ketika id dan ego nya tidak dapat dikendalikan dnegan super ego dengan baik. Gita lebih sering kehilangan kendali dengan apa yang ia lakukan. Ia termasuk ke dalam orang yang keras kepala dan memiliki rasa ingin tahu yang tinggi. Lambat laun Gita bisa berubah. Id yang dimiliki diimbangi dengan ego yang mampu di kendalikan oleh super ego. Konflik batin pada diri Gita adalah saat mengetahui perubahan yang ada pada diri Mas Gagah, Gita tidak terima. Pada akhirnya, super ego Gita lebih mendominasi dengan mengalahkan id pada dirinya. Konflik batin pada diri Gita sangat dipengaruhi oleh tokoh lain dan latar tempat, waktu, dan suasana. Mas Gagah adalah sosok yang diceritakan Gita berubah. Sosok Mas Gagah setelah berubah menjadi lebih baik, memiliki super ego yang sangat mendominasi. Sosoknya yang sabar, bijaksana, dan alim membuat super ego nya lebih dominan daripada id pada dirinya. Konflik batin paling menonjol yang dialami Mas Gagah dipengaruhi oleh latar tempat yaitu ketika ada di Madura dan tokoh seorang Kyai bernama Kyai Ghufron. Sosok Yudhistira Arifin yang muncul setelah Mas Gagah meninggal dan memberikan pengaruh pada diri Gita termasuk tidak memiliki konflik batin yang tidak menonjol bahkan hampir tidak ada konflik batin yang ada pada dirinya. Tokoh ini dominan karena menjadi salah satu pengaruh sosok Gita berubah. Sosok Yudi memiliki super ego tinggi melebihi Mas Gagah dan Gita. Super egonya menghantarkan Yudi untuk selalu berbuat baik dan menebar kebaikan di semua tempat.

Novelet Ketika Mas Gagah Pergi Karya Helvy Tiana Rosa memiliki nilainilai pendidikan karakter yang terkandung di dalamnya yang sangat beragam dan lengkap. Nilai-nilai tersebut dapat ditemui 
pada perwatakan maupun perilaku tokoh dalam novelet yang meliputi 15 nilai pendidikan karakter yaitu (1) religius, (2) jujur, (3) toleransi, (4) disiplin, (5) kerja keras, (6) kreatif, (7) mandiri, (8) demokratis, (9) rasa ingin tahu, (10) bersahabat/ komunikatif, (11) cinta damai, (12) gemar membaca, (13) peduli lingkungan, (14) peduli sosial, dan (15) tanggung jawab. Nilai yang paling dominan adalah nilai religius, cinta damai, penduli sosial, dan peduli lingkungan.

Novelet Ketika Mas Gagah Pergi

Karya Helvy Tiana Rosa relevan digunakan sebagai Bahan Ajar Sastra di SMA. dari aspek isi/materi, penyajian, bahasa, dan kegrafikaan sesuai dengan

\section{REFERENSI}

Aminudin. (2009). Pengantar Apresiasi Karya Sastra. Bandung: Sinar Baru.

Depdiknas. (2008). Panduan Pengembangan Bahan Ajar. Jakarta: Direktorat Pembinaan Sekolah Menengah Atas.

Ismawati, E. (2013). Pengajaran Sastra. Yogyakarta: Penerbit Ombak.

Kemendikbud. (2016). Peraturan Menteri Pendidikan dan Kebudayaan Nomor 8 Tahun 2016. Jakarta: Kemendikbud.

Kemendiknas. (2010). Pengembangan Pendidikan Budaya dan Karakter Bangsa (Pedoman Sekolah). Jakarta: Kemendiknas.

Minderop, A. (2013). Psikologi Sastra: Karya Sastra, Metode, Teori, dan
Permendikbud Nomor 8 Tahun 2016 tentang buku yang digunakan oleh satuan pendidikan. Novelet Ketika Mas Gagah Pergi karya Helvy Tiana Rosa dapat digunakan sebagai bahan ajar berupa buku nonteks kepribadian. Selain itu, salah satu tujuan pembelajaran sastra adalah mengembangkan kepribadian siswa dan menambah wawasan tentang kemanusiaan serta nilai-nilai positif yang ada dalam novelet. Oleh karenanya, novelet Ketika Mas Gagah Pergi karya Helvy Tiana Rosa memenuhi kriteria sebagai salah satu novelet yang dapat menjadi bahan ajar apresiasi sastra di SMA pada mata pelajaran Bahasa Indonesia kelas XII.
Contoh Kasus. Jakarta: Yayasan Pustaka Obor Indonesia.

Nurgiyantoro, B. (2005). Teori Pengkajian Fiksi. Yogyakarta: Gadjah Mada University Press.

Teeuw, A. (2015). Sastra dan Ilmu Sastra: Pengantar Teori Sastra. Bandung: PT. Dunia Pustaka Jaya.

Waluyo, H.J. (2011). Pengkajian dan Apresiasi Prosa Fiksi. Surakarta: UNS Press.

Wibowo, A. (2013). Pendidikan Karakter Berbasis Sastra. Yogyakarta: Pustaka Belajar.

Winkel, W.S. (2009). Psikologi Pengajaran. Yogyakarta: Media Abadi. 